\title{
1. Introduction: Principles as a framework for comparative analysis in international economic law ${ }^{1}$
}

I. INTRODUCTION

II. 'PRINCIPLES' AND THEIR RELATIONSHIP TO 'RULES'

A. Defining Principles and Distinguishing them from Rules

B. Sources of Principles Relevant to International Economic Law

1. Principles of international trade law and international investment law

2. Principles of customary international law

3. General principles of law

C. The Roles of Principles in International Economic Law

1. Principles as justification for the creation of rules

2. Principles as an aid in interpreting rules

3. Non-interpretative uses of principles by tribunals

III. PRINCIPLES AND THE COMPARATIVE STUDY OF INTERNATIONAL ECONOMIC LAW

A. The Purpose of a Comparative Study of Principles

B. The Importance of Identifying Both Similarities and Differences

C. The Separation and Convergence of the Regimes of International Trade Law and International Investment Law

IV. OUTLINE OF THE FOLLOWING CHAPTERS

1 Section II of this chapter draws in part on earlier research which was published in Andrew D Mitchell, Legal Principles in WTO Disputes (Cambridge University Press, 2008) and Andrew D Mitchell, 'The Legal Basis for Using Principles in WTO Disputes' (2007) 10(4) Journal of International Economic Law 795. 


\section{INTRODUCTION}

International trade law and international investment law are two pillars of the broader field of international economic law that emerged and developed in parallel for much of the twentieth century. ${ }^{2}$ The field of international trade law is, in many respects, dominated by the multilateral rules and institutional framework of the WTO, but also includes bilateral or regional preferential trade agreements (PTAs). The WTO oversees approximately 60 legal texts, ${ }^{3}$ and as of December 2020 its Dispute Settlement Body (DSB) had issued 381 reports that have been adopted by the WTO Members. ${ }^{4}$ In addition, as of December 2020, at least 305 PTAs were in force. ${ }^{5}$ International investment law is an even more disparate field, made up of bilateral, regional and sectoral treaties, with disputes being resolved by ad hoc arbitral panels. The United Nations Conference on Trade and Development (UNCTAD) reported that by December 2020 there were 2,663 international investment agreements (IIAs) in force, including both bilateral investment treaties (BITs) and other treaties incorporating investment provisions, ${ }^{6}$ and that there had been 1,061 investor-state arbitrations. ${ }^{7}$

This book provides an in-depth examination of how key principles of international economic law, such as reasonableness and procedural fairness, are reflected and applied in the fields of international trade law and international investment law. As outlined in the previous paragraph, these are two distinct fields or regimes of law, ${ }^{8}$ which sit within the broader fields of international

2 Tomer Broude, 'Investment and Trade: The "Lottie and Lisa" of International Economic Law?' in Roberto Echandi and Pierre Sauve (eds), Prospects in International Investment Law and Policy (Cambridge University Press, 2013) 139, 140.

3 See World Trade Organization, WTO Legal Texts, <https://www.wto.org/english/ docs_e/legal_e/legal_e.htm>.

${ }^{4}$ These include both panel reports and reports of the Appellate Body at 21 December 2020. For more detailed statistics, see WorldTradeLaw.net, Facts and Figures on WTO Dispute Settlement, <http://worldtradelaw.net/databases/basicfigures .php>.

5 See World Trade Organization, Regional Trade Agreements Information System (RTA-IS), <http://rtais.wto.org/UI/PublicMaintainRTAHome.aspx>.

6 United Nations Conference on Trade and Development(UNCTAD), International Investment Agreements Navigator, <https://investmentpolicy.unctad.org/international -investment-agreements>.

7 UNCTAD, Investment Dispute Settlement Navigator, <https://investmentpolicy .unctad.org/investment-dispute-settlement>.

8 For the purposes of this volume, we use the terms 'field' and 'regime' interchangeably with respect to international trade law and international investment law. We note that definitions of what constitutes a 'regime' can vary, and that there may be contestation as to whether a certain area of law constitutes a regime, and how differ- 
economic law, and public international law more generally. ${ }^{9}$ While several works have analysed the use of principles in one of these two fields, ${ }^{10}$ or have undertaken a detailed comparative analysis of how a single principle is treated in each regime, ${ }^{11}$ this is the first volume to undertake a comparative examination of several key principles across the two fields. This analysis allows for the identification of commonalities between the two fields, while remaining mindful of the complexity and variations within each body of law, which can provide insights into unique features and purposes of each field.

ent regimes are defined and distinguished. See Margaret A Young, 'Introduction: The Productive Friction between Regimes' in Margaret A Young (ed), Regime Interaction in International Law (Cambridge University Press, 2012) 1, 4-11; Andrew TF Lang, 'Legal Regimes and Professional Knowledges: The Internal Politics of Regime Definition' in Margaret A Young (ed), Regime Interaction in International Law: Facing Fragmentation (Cambridge University Press, 2012) 113. However, it is well accepted that international trade law and international investment law are each capable of being considered as distinct 'regimes', which are primarily defined by the scope of the treaties that contain the rules of that regime. See, eg, Andrew TF Lang, 'Reconstructing Embedded Liberalism: John Gerard Ruggie and Constructivist Approaches to the Study of the International Trade Regime' (2006) 9(1) Journal of International Economic Law 81; AM Johnston and MJ Trebilcock, 'Fragmentation in International Trade Law: Insights from the Global Investment Regime' (2013) 12(4) World Trade Review 621; Jeswald W Salacuse, 'The Emerging Global Regime for Investment' (2010) 51 Harvard International Law Journal 427; José E Alvarez et al (eds), The Evolving International Investment Regime (Oxford University Press, 2011); José E Alvarez, 'The Once and Future Foreign Investment Regime' in Mahnoush H Arsanjani and W Michael Reisman (eds), Looking to the Future: Essays on International Law in Honor of W. Michael Reisman (Martinus Nijhoff Publishers, 2011) 607.

9 On the relationship of individual regimes or fields of law to the wider 'system' of public international law, see, generally: 'Report of the International Law Commission on the Work of Its Fifty-Eighth Session (1 May - 9 June and 3 July - 11 August 2006)' [2006] II(2) Yearbook of the International Law Commission 176; Bruno Simma and Dirk Pulkowski, 'Of Planets and the Universe: Self-Contained Regimes in International Law' (2006) 17(3) European Journal of International Law 483.

10 See, eg, Andrew D Mitchell, Legal Principles in WTO Disputes (Cambridge University Press, 2008); Rudolf Dolzer and Christoph Schreuer, Principles of International Investment Law (Oxford University Press, 2nd ed, 2012); Andrea Gattini, Attila Tanzi and Filippo Fontanelli (eds), General Principles of Law and International Investment Arbitration (Brill Nijhoff, 2018).

${ }_{11}$ See, eg, Andrew Mitchell, David Heaton and Caroline Henckels, Non-Discrimination and the Role of Regulatory Purpose in International Trade and Investment Law (Edward Elgar Publishing, 2016); Andrew D Mitchell, Muthucumaraswamy Sornarajah and Tania Voon (eds), Good Faith and International Economic Law (Oxford University Press, 2015); Caroline Henckels, Proportionality and Deference in Investor-State Arbitration: Balancing Investment Protection and Regulatory Autonomy (Cambridge University Press, 2015) ch 3. 
This chapter proceeds as follows. Section II.A begins by providing a working definition of principles used in this volume and explains the relationship of 'principles' of law to 'rules'. It then goes on, in section II.B, to discuss the three sources of principles that are particularly relevant for the study of international economic law: principles derived from international trade law or international investment law themselves; principles of customary international law; and general principles of law. Section II.C provides a brief overview of the different roles or uses of principles in international economic law, including as the justification or theoretical foundation for rules, as aids for the interpretation of rules, or other non-interpretative uses by tribunals. Section III sets out the framework for the comparative approach taken in the following chapters, explaining why the fields of international trade law and international investment law are appropriate subjects for comparative study, as well as how principles offer a useful framework for undertaking such comparison. Section IV provides an outline of the following chapters.

\section{II. 'PRINCIPLES' AND THEIR RELATIONSHIP TO 'RULES'}

\section{A. Defining Principles and Distinguishing them from Rules}

Principles and rules are two species of legal norms (standards of conduct). ${ }^{12}$ The definition and scope of legal principles, and how those principles are distinguished from rules, is the subject of contentious scholarly debate. ${ }^{13}$ Yet

12 Joseph Raz, Practical Reason and Norms, (Oxford University Press, rev ed, 1999) ch 1; Brian Bix, A Dictionary of Legal Theory (Oxford: Oxford University Press, 2004) 149. Another important dichotomy that is often used to classify legal norms is the distinction between 'rules' (formal and mechanical norms that, if triggered, lead to a defined outcome) and 'standards' (more flexible and discretionary norms, that require judgement to be exercised by the adjudicator). See, generally, Pierre Schlag, 'Rules and Standards' (1985) 33 UCLA Law Review 379; Duncan Kennedy, 'Form and Substance in Private Law Adjudication' (1976) 89(8) Harvard Law Review 1685; Cass R Sunstein, 'Problems with Rules' (1995) 83 California Law Review 953. In this book, as with other work that classifies legal norms using a 'rule-principle' dichotomy, the term 'rule' is used more broadly than it is in the 'rule-standard' dichotomy, and includes both mechanical rules with a clear factual trigger that lead to a predefined outcome, and more flexible/evaluative standards. See Larry Alexander and Ken Kress, ‘Against Legal Principles' (1996) 82 Iowa Law Review 739, 740.

13 For a critique of the distinction between rules and principles, particularly as that distinction was conceived by Ronald Dworkin, see: Alexander and Kress (n 12); George C Christie, 'The Model of Principles' (1968) 1968(4) Duke Law Journal 649, 655-668; Joseph Raz, 'Legal Principles and the Limits of Law' (1972) 81 The Yale Law Journal 823, 834-842. 
'[m]ost legal thinkers_-judges, litigators, legal scholars, legal philosophersbelieve that legal rules and legal principles are meaningfully distinguished. ${ }^{14}$ For the purposes of this volume, it is unnecessary to offer a novel or definitive explication of the distinction between principles and rules. ${ }^{15}$ Instead, this section provides an overview of commonly identified features of legal principles, and their relationship to rules.

In essence, principles can be defined as fundamental propositions, basic tenets or underlying assumptions. ${ }^{16}$ Although it may be tempting to define principles chiefly by reference to their breadth or how they are often defined in abstract terms, all laws have only a core of settled meaning and an uncertain penumbra, ${ }^{17}$ and consequently rules are also frequently (if not always) vague and indeterminate. ${ }^{18}$ Ronald Dworkin's work has been viewed as one of the most thorough expositions of the distinction between rules and principles. ${ }^{19}$ Dworkin suggests that rules generally operate in a binary manner, a feature that principles lack. ${ }^{20}$ When the conditions for the application of a given rule have been satisfied, the rule operates to provide a determinative result to the legal problem; when the conditions for the application of the rule have not been satisfied, the rule has no operation. ${ }^{21}$ A principle cannot lead to a determinative result or solution, because it must be applied taking account of the particular situation in dispute, and often competing principles must be balanced or weighed against one another. ${ }^{22}$ Thus, a principle may 'incline' a decision one way or another, but it does not determine the result. ${ }^{23}$ In a similar vein, Eckhoff and Sundby state that rules either apply or do not apply, whereas principles are guidelines that are more or less relevant and persuasive in determining the preferable solution. ${ }^{24}$

14 See, generally, Mitchell N Berman, For Legal Principles (Legal Scholarship Repository - Faculty Scholarship No 1759, University of Pennsylvania Law School, 20 June 2017) 1.

15 Section III, below, identifies three broad categories of principle that are of particular relevance to international economic law, and each of these categories of principle can be defined with relative precision.

16 'principle, n.' OED Online, Oxford University Press, June 2018.

17 HLA Hart, The Concept of Law (Oxford University Press, 1961) 120.

18 See, generally, Timothy Endicott, Vagueness in Law (Oxford University Press, 2000).

19 Alexander and Kress (n 12) 745.

20 Ronald Dworkin, Taking Rights Seriously (Harvard University Press, 1978) 24-28.

21 Ibid 26.

22 Ibid 27.

23 Ibid 35.

24 As referred to in: Martti Koskenniemi, 'General Principles: Reflexions on Constructivist Thinking in International Law’ (1985) XVIII Oikeustiede-Jurisprudentia $117,135$. 
A second important feature of Dworkin's definition of principles is that they have a dimension of 'weight' or importance that rules alone may lack. ${ }^{25}$ Principles emerge and gain their weight from the amalgam of practice, including the adoption of statutory rules and the making of juridical decisions, as well as from other principles. ${ }^{26}$ Thus, although principles themselves 'are not posited and have no canonical form', they 'reflect and can be changed by changes in posited, canonical legal norms (rules)' ${ }^{27}$ In domestic legal systems, a principle may be reflected in several different rules ${ }^{28}$ and can be identified as the 'common denominator' of those rules. ${ }^{29}$ In international law, it can be trickier to distinguish between rules and principles in this way, because some principles of international law, such as non-intervention, may not be reflected in more detailed rules. ${ }^{30}$

This general sketch of the distinction between rules and principles shows that the relationship between these two categories of norms is two-directional and mutually reinforcing. As noted above, principles embody fundamental regulatory purposes or values that can serve as a guide for the development and application of rules that target specific behaviour or seek to resolve particular problems. ${ }^{31}$ In this respect, principles may serve as the basis for the development of rules, or as the fundamental propositions that justify more specific rules. Yet, rules may also serve as evidence or support for the existence of certain principles within a legal regime, and developments in the content of rules may reshape the legal principles underlying that regime.

These two aspects of the relationship between principles and rules reflect two different theories about principles: ${ }^{32}$ a normative theory, under which principles are the higher norms that influence the rest of the legal system and can be used to justify rules; ${ }^{33}$ and a descriptive theory, under which principles

\footnotetext{
25 Dworkin (n 20) 26-27.

26 Ibid 36-40.

27 Alexander and Kress (n 12) 741.

28 Koskenniemi (n 24) 132.

29 JF O'Connor, Good Faith in International Law (Dartmouth, 1991) 122.

30 Koskenniemi (n 24) 132; Mitchell (n 10) 9.

31 Neil MacCormick, Legal Reasoning and Legal Theory (Oxford: Oxford University Press, 1994).

32 For further discussion of these two theories and the distinction between them, see: Koskenniemi (n 24) 126-128; David M Walker, The Oxford Companion to Law (Oxford University Press, 1980) 989-990.

33 For an adoption of this approach, see Gerald Fitzmaurice, 'The General Principles of International Law Considered from the Standpoint of the Rule of Law' (1957) 92 Recueil des Cours 1, 7. Perry offers two further models of principles that fall within this theory: the rationalisation model and the normative primacy model. See Stephen R Perry, ‘Two Models of Legal Principles' (1997) 82 Iowa Law Review 787.
} 
are inductive generalisations of the rules of a specific legal regime. ${ }^{34}$ In this volume, it is not necessary to determine whether one of these theories is the correct or preferable characterisation of the relationship between principles and rules. The two theories are not necessarily mutually exclusive, and many principles of international economic law can be identified and understood using either a normative or descriptive approach, or both. ${ }^{35}$

\section{B. Sources of Principles Relevant to International Economic Law}

Article 38(1) of the ICJ Statute famously sets out the key sources of international law. Principles that are relevant to international economic law may emerge from the three primary sources of international law, as set out in paragraphs (a)-(c) of Article 38(1): treaty law, customary international law, and general principles of law. The first of these sources - treaties-forms the backbone of the international trade law and international investment law regimes. However, both these regimes form part of the broader field of public international law, ${ }^{36}$ meaning that customary international law and general principles of law may also be relevant sources of law and legal principles in the context of international economic law. We elaborate on these three sources of law in international economic law in the following sections.

34 For work pioneering the use of this approach in the context of international law, see, generally: Georg Schwarzenberger, The Inductive Approach to International Law (Stevens \& Sons Limited, 1965); Bin Cheng, General Principles of Law as Applied by International Courts and Tribunals (Stevens \& Sons Limited, 1953).

35 See Mitchell (n 10) 10-11.

36 With regard to international trade law, while it has sometimes been posited that the WTO is a self-contained regime, it has been acknowledged by the Appellate Body that the WTO agreements 'cannot be read in clinical isolation from public international law' as a whole: Appellate Body Report, US - Gasoline, 17. See further Gabrielle Marceau, 'Conflicts of Norms and Conflicts of Jurisdictions: The Relationship between the WTO Agreement and MEAs and Other Treaties' (2001) 35 Journal of World Trade 1081; Joost Pauwelyn, 'The Role of Public International Law in the WTO: How Far Can We Go?' (2001) 95 The American Journal of International Law 535; Joost Pauwelyn, 'Interplay Between the WTO Treaty and Other International Legal Instruments and Tribunals: Evolution After 20 Years of WTO Jurisprudence' in C-E Côté, V Guèvremont, R Ouellet (eds) Proceedings of the Québec City Conference on the WTO at 20 (Presses de l'Université de Laval, 2018); Graham Cook, A Digest of WTO Jurisprudence on Public International Law: Concepts and Principles (Cambridge University Press, 2015). With regard to international investment law, as the relevant instruments (IIAs) are bilateral or regional treaties, it is relatively uncontroversial that these exist against the general backdrop of public international law. In fact, many IIAs include an explicit provision stating that the governing law for any dispute arising under the treaty is the rules of that '[a]greement and applicable rules of international law'. See, eg, NAFTA art 1131(1). 


\section{Principles of international trade law and international investment law}

The primary source of the principles that are discussed in this volume are the fields of international trade law and international investment law themselves. It is generally accepted that there are both principles of international trade law, particularly WTO law, ${ }^{37}$ and of international investment law. ${ }^{38}$ In both fields, treaties make up the key source of these principles: in international trade law, the relevant treaties are primarily the WTO agreements, but also PTAs; and in international investment law, the relevant treaties include the thousands of individual bilateral and regional IIAs. As explained above, principles are the 'intellectual foundations of any legal order'. ${ }^{39}$ Thus, not all rules contained within the WTO agreements, PTAs or IIAs are 'principles' of the relevant field of law.

Although principles of international trade law and international investment law relate to written agreements, the specific principles themselves may be unwritten. As explained in section II.A above, principles can be identified using either a normative approach or a descriptive approach. A normative approach to finding the principles of a legal regime may begin with a consideration of the objects and purposes of that regime, or may involve a consideration of the values that would best justify its core rules; in other words, to look for the intellectual assumptions or foundations of the regime. A descriptive approach to identifying the principles of a regime would start with the treaty rules themselves, looking for common themes or categories which could be summarised to find the abstractions that best explain the rules. As we show in this volume, principles of international economic law can be identified using either method, or a combination of these approaches.

\section{Principles of customary international law}

The classical position is that the formation of customary international law requires two elements: consistent state practice (the objective element), and a belief that the practice is obligatory or legally required (the subjective element, often referred to as opinio juris). ${ }^{40}$ Although the existence and identification of rules of customary international law has been the subject of

\footnotetext{
See, generally, Mitchell (n 10).

See, generally, Dolzer and Schreuer (n 10); Gattini, Tanzi and Fontanelli (n 10).

Sujit Choudhry, 'Globalization in Search of Justification: Toward a Theory of Comparative Constitutional Interpretation' (1999) 74 Indiana Law Journal 819, 843.

${ }_{40}$ See North Sea Continental Shelf (Federal Republic Germany v Denmark; Federal Republic of Germany v Netherlands) (Judgment) [1969] ICJ Rep 3, 44, para.
} 77. 
significant academic controversy and critique, ${ }^{41}$ the ICJ has applied customary international law in numerous cases. ${ }^{42}$

Norms of customary international law are relevant to international trade law and international investment law in various ways. For instance, the WTO agreements acknowledge that their provisions must be interpreted in accordance with the 'customary rules of interpretation of public international law'. ${ }^{43}$ In settling investor-state disputes under IIAs, tribunals have referred to norms of customary international law, either as applicable $1 \mathrm{law}^{44}$ or as an aid in interpreting treaty rules. ${ }^{45}$ International economic agreements may also contribute to the formation or evolution of norms of customary international law. For example, some arbitral tribunals established under IIAs have noted that the customary minimum standard of treatment of aliens has been 'shaped by the conclusion of more than two thousand bilateral investment treaties', which provide for the 'fair and equitable treatment' of foreign investors. ${ }^{46}$

\section{General principles of law}

A third source of international law set out in Article 38(1) of the ICJ Statute is the 'general principles of law recognised by civilised nations'. The Advisory Committee of Jurists who drafted the ICJ Statute included 'general principles' as a source because of the fear that issues might come before the Court that were 'not governed by any treaty, and that no rule of customary law could be

${ }^{41}$ See, eg, Patrick Kelly, 'The Twilight of Customary International Law' (2000) 40 Virginia Journal of International Law 449; Vladimir Degan, Sources of International Law (Martinus Nijoff, 1997) 146.

42 See, eg, North Sea Continental Shelf (Federal Republic Germany v Denmark; Federal Republic of Germany $v$ Netherlands) (Judgment) [1969] ICJ Rep 3, 44, para. 77; Military and Paramilitary Activities in and against Nicaragua (Nicaragua $v$ United States) (Merits) [1986] ICJ Rep 14, 97, para. 183, 110, para. 211; Legality of the Threat or Use of Nuclear Weapons (Advisory Opinion) [1996] ICJ Rep 226, 253-55, paras. 65-73.

43 See DSU art 3.2; Anti-Dumping Agreement art 17.6(ii).

44 For example, when considering the application of the customary international law defence of necessity. See, eg, CMS v Argentina, Award, [122], [315]-[331]; Sempra v Argentina, Award, [333]-[354]; LG\&E v Argentina, Decision on Liability, [245]-[259].

${ }_{45}$ For example, using the minimum standard of treatment of aliens as a benchmark for applying the 'fair and equitable treatment' standard. See, eg, Genin v Estonia, Award, [366]-[367]; Azurix v Argentina, Award, [361]; Rumeli Telekom v Kazakhstan Award, [611].

46 Mondev v United States, Award, [125]. See also ADF Group v US, Award, [179]; Stephen M Schwebel, 'The Reshaping of the International Law of Foreign Investment by Concordant Bilateral Investment Treaties' in Steve Charnovitz, Debra P Steger and Peter Van den Bossche (eds), Law in the Service of Human Dignity (Cambridge University Press, 2005) 241. 
found to determine them' ${ }^{47}$ One of the major contentions regarding the identification of general principles is whether they must be based in international law or in the domestic law of states. In his seminal work identifying such general principles, Bin Cheng notes:

Some writers consider that the expression refers primarily to general principles of international law and only subsidiarily to principles obtaining in the municipal law of the various States. Others hold that it would have been redundant for the Statute to require the Court to apply general principles of international law, and that, therefore, this provision can refer only to principles obtaining in municipal law. ${ }^{48}$

Nevertheless, it is relatively uncontroversial that standards common to all or a majority of municipal legal systems constitute general principles of law within the meaning of Article 38(1)(c). ${ }^{49}$ These principles are derived through a comparative examination of different municipal legal systems. ${ }^{50}$ In addition, general principles may include those principles that are applicable directly to international legal relations, or those that are applicable to legal relations generally (whether domestic or international). ${ }^{51}$ Although the inclusion of principles of international law within Article 38(1)(c) of the ICJ Statute has been controversial at times, the ICJ has in certain cases applied general principles of law based on international law, ${ }^{52}$ and many scholars now recognise the validity of this approach. ${ }^{53}$

47 Hugh WA Thirlway, The Sources of International Law (Oxford University Press, 2014) 93 .

${ }_{48}$ Cheng (n 34) 2-3 (footnotes omitted). See also Maurice Mendelson, 'The International Court of Justice and the Sources of International Law' in Vaughan Lowe and Malgosia Fitzmaurice (eds), Fifty Years of the International Court of Justice (Cambridge: Cambridge University Press, 1996) 63, 80.

49 Christian Dominicé, 'Methodology of International Law' in Rudolf Bernhardt (gen ed), Encyclopaedia of Public International Law (Elsevier, 2003) Vol 3, 354, 358.

50 Thirlway (n 47) 95.

51 See ibid 96; Andrew D Mitchell, 'The Legal Basis for Using Principles in WTO Disputes’ (2007) 10(4) Journal of International Economic Law 795, 801.

52 See the ICJ's references to clearly 'international' principles of non-intervention and the use of force (Military and Paramilitary Activities in and Against Nicaragua (Nicaragua $v$ United States of America) (Merits) [1986] ICJ Rep 14, 99-100, 106-7) and the principle that delimitations of the continental shelf should occur by agreement where possible (Case Concerning Delimitation of the Maritime Boundary in the Gulf of Maine Area (Canada v United States of America) (Merits) [1984] ICJ Rep 246, 292-93).

53 See, eg, Rebecca Wallace, International Law (Sweet \& Maxwell, , 4th ed, 2002) 22; Hilary Charlesworth and Christine Chinkin, The Boundaries of International Law: A Feminist Analysis (Manchester University Press, 2000) 64. 


\section{The Roles of Principles in International Economic Law}

Antonio Cassese describes principles as 'basic guidelines for the life of the whole community'. ${ }^{54}$ As the over-arching tenets or fundamental assumptions underlying a legal system, principles can play many different roles within a legal regime. Principles may 'inspir[e]' both the 'legislator and the law-applier'. ${ }^{55}$ Three core roles of principles can be identified. First, principles can be the justification or motivation for the creation of rules. Second, principles can be used as tools to assist in interpreting or applying those rules. The uses of principles which we focus on this in volume fall into these two categories. For completeness, however, we note the third role of principles, which are non-interpretative uses in dispute settlement (such as invoking certain principles pursuant to inherent jurisdiction to resolve procedural matters in the absence of clear rules). ${ }^{56}$

\section{Principles as justification for the creation of rules}

In the first of these roles, principles are the higher norms that influence and justify the design of rules. In the field of international economic law, this role typically means that principles influence the content of treaty provisions. This role of principles reflects the view of Gerald Fitzmaurice, who posited that a "rule answers the question "what": a principle in effect answers the question "why". ${ }^{57}$ However, in some cases the relevant rules may reflect a principle only to a limited extent or may be an imperfect expression of the relevant principle. ${ }^{58}$ For example, Chapter 2 considers how the principle of procedural fairness is given meaning, to varying extents, in specific rules of international trade law and international investment law.

\section{Principles as an aid in interpreting rules}

Treaty drafters cannot anticipate every situation to which a given rule may apply, or the unexpected circumstances that may arise. Consequently, treaty rules almost always have a degree of ambiguity or vagueness, requiring careful interpretation to determine the most appropriate construction. Article 31 of the VCLT provides the general rule to be followed for the interpretation of treaty

\footnotetext{
54 Antonio Cassese, International Law (Oxford University Press, 2nd ed, 2005) 46.

55 Robert Kolb, 'Principles as Sources of International Law (With Special Reference to Good Faith)' (2006) 53(1) Netherlands International Law Review 1, 7.

56 See, eg, Andrew Mitchell and David Heaton, 'The Inherent Jurisdiction of WTO Tribunals: The Select Application of Public International Law Required by the Judicial Function' (2010) 31 Michigan Journal of International Law 561.

57 Fitzmaurice (n 33) 7.

58 Cheng (n 34) 376.
} 
provisions. The WTO Appellate Body and many arbitral tribunals applying IIAs have acknowledged that the interpretative approach set out in Article 31 of the VCLT codifies the customary international law of treaty interpretation. ${ }^{59}$ The basic rule, contained in paragraph (1) of Article 31, states that treaty provisions should be interpreted 'in good faith in accordance with the ordinary meaning to be given to the terms of the treaty in their context and in the light of its object and purpose'. The context of the treaty includes, inter alia, its text and any preamble. ${ }^{60}$

Under the approach required by Article 31, principles can provide useful guidance for the interpretation of rules contained in treaties, although the role of a principle may depend on its source. ${ }^{61}$ Principles that are expressed in the treaty itself - for example, in the preamble or in other provisions - are a part of the context in which the treaty must be interpreted. For example, Chapter 5 considers how the object and purpose of the WTO agreements and IIAs reveal that rules relating to non-discrimination in international economic law should be applied in line with the principle that protectionist measures should be disciplined, but that differential treatment of goods, services or investors is permissible where justified by a legitimate public purpose.

Principles drawn from customary international law or general principles of law may also be relevant in interpreting rules in international trade or investment treaties, as part of the 'relevant rules of international law applicable between the parties' under VCLT Article 31(3)(c). ${ }^{62}$ However, the use of customary international law in the interpretation of treaty rules may be inapro-

59 See Appellate Body Report, US - Gasoline, pp. 16-17; Appellate Body Report, US - Carbon Steel, [61]-[62]; Appellate Body Report, US - Shrimp, [114]; Koch Minerals v Venezuela, Award, [6.50]; Yukos Universal Ltd v Russian Federation, Final Award, [1344]; Mobil and Murphy Oil v Canada, Decision on Liability, [254]; Mesa Power v Canada, Award, [232]. As noted above, some of the WTO agreements make specific references to how their interpretation should be carried out in accordance with customary international law. See DSU art 3.2; Anti-Dumping Agreement art 17.6(ii).

60 VCLT art 31(2).

61 This is discussed more fully in Mitchell (n 51).

${ }^{62}$ VCLT, art 31(3)(c). On the use of external rules of public international law in interpreting the WTO agreements, see, generally, Pauwelyn (n 36); Joost Pauwelyn, 'Sources of International Trade Law: Mantras and Controversies at the World Trade Organization' in Samantha Besson and Jean d'Aspremont (eds), The Oxford Handbook on the Sources of International Law (Oxford University Press, 2017) 1027, 1034-40 ('Sources of International Trade Law'). On the use of external rules of public international law in interpreting IIAs, see J Romesh Weeramantry, Treaty Interpretation in Investment Arbitration (Oxford University Press, 2012) [3.133][3.149]; Campbell McLachlan, Laurence Shore and Matthew Weiniger, International Investment Arbitration: Substantive Principles (Oxford University Press, 2nd ed, 2017) [3.131]-[3.134]. 
priate in some circumstances. For example, Chapter 4 examines controversies that have arisen when non-precluded measures clauses in IIAs have been interpreted in light of the customary international law defence of necessity.

\section{Non-interpretative uses of principles by tribunals}

In addition to principles providing guidance for the interpretation of rules or treaty provisions, tribunals use principles in a variety of other contexts. For example, a principle of law could, in certain circumstances, provide the basis for a claim or for subject-matter jurisdiction, or may be applied under the inherent jurisdiction of the tribunal to resolve procedural matters. Controversy exists as to whether or to what extent rules from outside the WTO covered agreements can form part of the law applicable to a WTO dispute, ${ }^{63}$ and thus, whether principles drawn from customary international law or general principles of law could be used in a non-interpretative manner by a WTO panel or the Appellate Body. ${ }^{64}$ In relation to international investment law, the use of customary international law or general principles of law in a non-interpretative manner may be less controversial, as many IIAs refer explicitly to public international law or general principles of international law within the applicable law in investor-state disputes. ${ }^{65}$ The appropriateness of using a principle in any of these ways will depend on the terms under which the tribunal has been appointed, such as the WTO DSU, as well as the source of the relevant principle. For the purposes of this volume, it is not necessary to resolve whether principles drawn from public international law may be used in either WTO dispute settlement or in investor-state arbitration. It is sufficient to note that such a use of principles is possible and may be relevant to both regimes. For example, good faith is a general principle that underlies many legal regimes, and may operate to provide tribunals in international trade law and international investment law with solutions to difficult procedural issues where rules are absent or ambiguous. ${ }^{66}$

\footnotetext{
63 See Pauwelyn 'Sources of International Trade Law' (n 62).

${ }^{64}$ For a comprehensive discussion of these issues, see Mitchell (n 51); Mitchell (n $10)$.

65 See, eg, NAFTA art 1132; ECT art 26(6); Netherlands-Czech and Slovak Republic BIT (1991) art 8(6). For a discussion of the use of international law as applicable law in investment arbitration, taking account of differences between UNCITRAL and ICSID arbitration rules, see Giorgio Sacerdoti, 'Arbitration of Investment Disputes under UNCITRAL Rules and the Choice of Applicable Law' in Steve Charnovitz, Debra P Steger and Peter Van den Bossche (eds), Law in the Service of Human Dignity (Cambridge University Press, 2005) 276, 287-98.

66 See, generally, Tania Voon, Andrew D Mitchell and James Munro, 'Good Faith in Parallel Trade and Investment Disputes' in Andrew D Mitchell, M Sornarajah and
} 


\section{PRINCIPLES AND THE COMPARATIVE STUDY OF INTERNATIONAL ECONOMIC LAW}

At its most basic level, '[t]o compare means to observe and to explain similarities as well as differences' ${ }^{67}$ Although comparative studies of law often focus on comparing different national legal systems, ${ }^{68}$ this methodology can also be fruitfully applied to different branches of public international law that may have diverged as a result of pluralism or fragmentation. ${ }^{69}$ This volume undertakes a comparative examination of how certain principles of law are treated across the international trade law and international investment law regimes. This section provides the theoretical grounding for this study, by considering why it is appropriate to apply comparative methodology to a study of these two fields of international economic law, and why principles are an appropriate subject for that comparative analysis.

\section{A. The Purpose of a Comparative Study of Principles}

Comparison as a methodology for the study of law and legal systems can be used for a range of purposes, including to assist us to better understand law and legal systems, to systematise law across a range of jurisdictions, to universalise law or legal principles, or as a tool in the critique of law. ${ }^{70}$ Comparative legal methodology relies on the identification of a common denominator between the legal systems that are being examined, often referred to as the tertium comparationis. Identifying the common subject for comparison does not require that the legal norms or processes be obviously similar to one another, and may instead be 'a shared feature or function by means of which comparison becomes sensible'. ${ }^{71}$ The dominant or traditional approach to comparative law

Tania Voon (eds), Good Faith and International Economic Law (Oxford University Press, 2015) 60.

67 Rudolf B Schlesinger, 'The Past and Future of Comparative Law' (1995) 43(3) The American Journal of Comparative Law 477, 477.

68 Additionally, 'vertical' comparative law examines how national legal norms, rules or principles may be translated to the international level. See, generally, Aleksandar Momirov and Andria Naude Fourie, 'Vertical Comparative Law Methods: Tools for Conceptualising the International Rule of Law' (2009) 2 Erasmus Law Review 291.

69 Jaakko Husa, A New Introduction to Comparative Law (Hart Publishing, 2015) 54.

70 See, generally, Ralf Michaels, 'The Functional Method of Comparative Law' in Mathias Reimann and Reinhard Zimmerman (eds), The Oxford Handbook of Comparative Law (Oxford University Press, 2006) 339, 363-79.

71 Husa (n 69) 148. 
is functional comparative law, where the subjects for comparison are identified by the function that they perform, even if the relevant legal norms or processes are markedly different in form. ${ }^{72}$

The principles examined in this volume relate to common problems or issues addressed by both international trade law and international investment law. In Chapter 5 we examine non-discrimination obligations, which are drafted in relatively similar terms across the WTO agreements and IIAs, and which we argue reflect a common principle. However, for other principles covered in the book - such as reasonableness or procedural fairness - the related rules may be phrased in different terms but address a similar problem or issue. Thus, the study of principles undertaken in this book is largely an exercise in functional comparative law.

In addition to the similar function that a particular principle might play in international trade law and international investment law, a comparative study of the use of principles across these two fields also provides important insight into each regime. As discussed above, while rules are the 'what' of any legal regime, it is principles that provide the 'why'. ${ }^{73}$ In other words, '[p]rinciples are the pinnacle of the legal system, ${ }^{74}$ and examining them reveals the ideological assumptions and motivations that underpin a regime. Identifying commonalities and divergences in how the two regimes treat key principles illuminates the purpose of each regime, while furthering our understanding of the broader fields of international economic law and public international law.

\section{B. The Importance of Identifying Both Similarities and Differences}

Depending on the purpose of the comparative analysis, either the similarities or differences between the systems under comparison may be accented. ${ }^{75}$ For example, comparison can be used in an effort to unify different systems of law: a process that will naturally emphasise the similarities between those systems. Alternatively, comparison may be used as a tool for evaluating different legal techniques or approaches, which may require greater emphasis on the differences between the systems being studied. Engaging in functionalist comparison examines how different legal systems address common problems,

72 Michaels (n 70) 340; Husa (n 69) 118. Alternative methods for undertaking comparative study of law are comparative legal history, the study of legal transplants, or the study of different legal cultures. Michaels (n 70) 341.

73 Fitzmaurice (n 33) 7.

74 Antonio Cassese, International Law (Oxford University Press, 2nd ed, 2005) 46.

75 Schlesinger (n 67) 477; Gerhard Danneman, 'Comparative Law: Study of Similarities or Differences?' in Mathias Reimann and Reinhard Zimmerman (eds), The Oxford Handbook of Comparative Law (2006) 384, 384-85. 
and often such systems will produce similar results, despite different histories, structures or styles. Thus, functional comparative law has sometimes been accused of creating a presumption of similarity. ${ }^{76}$

In this volume, the aim of comparing the treatment of the selected principles in international trade law and international investment law is not to argue that either takes a superior approach, or to argue that a unified approach to the treatment of principles across the two regimes is necessarily preferable. Instead, each principle is considered individually with respect to similarities and differences in its treatment across the two regimes. As Otto Hinze has noted, comparative studies should search for both similarities and differences, because '[c]omparison may look for something general on which the compared objects are based', or it 'may seek to gain a sharper image of the individuality of one of the objects compared' ${ }^{77}$ Where similarities are identified, this may suggest that the relevant principle is a general or unifying feature of international economic law, while differences in how the two regimes treat a particular principle may provide insight into the unique features of each field of international economic law.

\section{The Separation and Convergence of the Regimes of International Trade Law and International Investment Law}

When selecting regimes for comparative examination, as Danneman argues, sufficient commonality is required for them to be appropriate subjects for comparison, but also sufficient divergence to 'make a comparative enquiry worthwhile'. ${ }^{78}$ As a result of the historical separation between international trade law and international investment law, the two regimes have often been considered as distinct and separate from one another. In the post-World War II development of our current international economic architecture, ${ }^{79}$ international trade law was institutionally separate from international investment law. ${ }^{80}$ The trade regime was shaped by the GATT 1947, and rounds of successive nego-

76 See Danneman (n 75) 388. Cf Michaels (n 70) 369-72.

77 Otto Hintze, 'Soziologische und geschichtliche Staatsauffassung' (1929), in Otto Hintze, Gesammelte Werke (ed G. Oestreich, vol II, 1964), 239 ft, 251, as translated in Danneman (n 75) 400.

78 Ibid 409.

79 The friendship, commerce and navigation $(\mathrm{FCN})$ treaties that were common prior to World War II included both trade- and investment-related provisions. See Kenneth J Vandevelde, 'A Brief History of International Investment Agreements' (2005) 12 U.C. Davis Journal of International Law \& Policy 157, 158-61.

80 See, generally, Broude (n 2); Jürgen Kurtz, The WTO and International Investment Law: Converging Systems (Cambridge University Press, 2015) 1-5; Nicholas DiMascio and Joost Pauwelyn, 'Nondiscrimination in Trade and Investment 
tiations that built on that framework, which eventually led to the formation of the WTO in 1995. In contrast to the WTO regime-a single multilateral institution that allows only for state-state dispute settlement-international investment law developed as a complex web of several thousand IIAs, which grant protections to individual foreign investors, that they may enforce through ad hoc arbitrations. However, despite the two fields developing as separate and distinct, they are increasingly recognised as closely related with many common norms, and a growing body of comparative scholarship. ${ }^{81}$

Much of the comparative analysis that has been undertaken to date focuses on cross-fertilisation of norms from the international trade regime to the international investment regime. In part, this focus arises because a number of the arbitral tribunals appointed to resolve investment treaty disputes have referred to the decisions of WTO panels, the Appellate Body or GATT panels in interpreting and applying an IIA. ${ }^{82}$ Some of these tribunals have been criticised by commentators for borrowing from the international trade regime without sufficient critical analysis, ${ }^{83}$ while some other tribunals have emphasised the significant contextual differences between the two regimes, which suggest that an investment norm cannot necessarily be interpreted in the same way as an equivalent trade law norm. ${ }^{84}$ For example, the tribunal in the Methanex

Treaties: Worlds Apart or Two Sides of the Same Coin?' (2008) 102 American Journal of International Law 48, 51-53.

${ }^{81}$ Selected examples from this body of comparative scholarship are: Andrew D Mitchell and Caroline Henckels, 'Variations on a Theme: Comparing the Concept of "Necessity" in International Investment Law and WTO Law' (2013) 14(1) Chicago Journal of International Law 93; Mitchell, Heaton and Henckels (n 11); Kurtz (n 80); Sungjoon Cho and Jürgen Kurtz, 'Convergence and Divergence in International Economic Law and Politics’ (2018) 29(1) European Journal of International Law 169; Andrea K Bjorklund, 'Convergence or Complementarity?' (2014) 12(1) Santa Clara Journal of International Law 65; Roger Alford, 'The Convergence of International Trade and Investment Arbitration' (2014) 12(1) Santa Clara Journal of International Law 35; DiMascio and Pauwelyn (n 80); Andrew D Mitchell, Elizabeth Sheargold and Tania Voon, 'Good Governance Obligations in International Economic Law: A Comparative Analysis of Trade and Investment' (2016) 17(1) The Journal of World Investment \& Trade 7.

82 See, eg, Continental Casualty v Argentina, Award, [192]-[195]; Total SA v Argentina, Decision on Liability, [123]; Feldman v Mexico, Award, [177].

83 See, eg, Jurgen Kurtz, 'The Use and Abuse of WTO Law in Investor-State Arbitration: Competition and Its Discontents' (2009) 20(3) European Journal of International Law 749; José Enrique Alvarez and Tegan Brink, 'Revisiting the Necessity Defense: Continental Casualty v. Argentina' in Karl P Sauvant (ed), Yearbook on International Investment Law and Policy 2010-2011 (Oxford University Press, 2011) 319.

${ }^{84}$ See, eg, Pope \& Talbot v Canada, Award on the Merits Phase 2, [57]; Occidental $v$ Ecuador I, Award, [176]. 
award, when considering the non-discrimination requirement in Chapter 11 of NAFTA, noted that language used by the drafters showed that 'trade provisions were not to be transported to investment provisions'. ${ }^{85}$ Thus, the simple fact that investment treaty arbitral tribunals are engaging in comparative analysis does not necessarily demonstrate that the methodology is appropriate or apposite in any or all instances.

However, at least four links between these two regimes make them appropriate subjects for comparative analysis. First, many norms are common to the two regimes, such as non-discrimination obligations or due process requirements. ${ }^{86}$ Exceptions clauses are one area in which the two fields have converged in the past decade, with many contemporary IIAs incorporating general exceptions modelled on Article XX of GATT. ${ }^{87}$

Second, the sources of international trade law and international investment law are increasingly connected, through what Jürgen Kurtz describes as 'common and important legal terrain' shared between the two systems. ${ }^{88}$ In particular, more and more IIAs take the form of a chapter within a PTA, and investment protections have an increasingly complex relationship with trade norms, particularly with regard to liberalisation of trade in services through

85 Methanex $v$ US, Award, Pt. IV, Chp. B, [35]-[37]. Whether the tribunal in Methanex was resolutely opposed to the use of trade law jurisprudence in the interpretation of Chapter 11 of NAFTA may be a point of contention, with a later tribunal characterising the Methanex position as 'expressly recogniz[ing] the relevance of GATT/ WTO jurisprudence' for the national treatment obligation contained in article 1102 of NAFTA. Corn Products v Mexico, Decision on Responsibility, [121]-[123]. The Corn Products tribunal agreed that the trade law precedents were not directly applicable or binding in the interpretation of the investment norm in article 1102 due to differences in the language used: ibid [121]. However, the Corn Products tribunal felt that a GATT decision on whether two products were 'like' was 'highly relevant' to the application of the national treatment obligation in article 1102: ibid [122].

86 On non-discrimination, see Mitchell, Heaton and Henckels (n 11); DiMascio and Pauwelyn (n 80); Jürgen Kurtz, 'The Merits and Limits of Comparativism: National Treatment in International Investment Law and the WTO' in Stephan W Schill (ed), International Investment Law and Comparative Public Law (Oxford University Press, 2010). On due process and good governance requirements, see Mitchell, Sheargold and Voon (n 81).

87 See, generally, Kurtz (n 80) ch 5; Andrew D Mitchell, James Munro and Tania Voon, 'Importing WTO General Exceptions into International Investment Agreements: Proportionality, Myths and Risks' in Lisa Sachs, Lise Johnson and Jesse Coleman (eds), Yearbook on International Investment Law \& Policy 2017 (Oxford University Press, 2019) 305; Andrew Newcombe, 'The Use of General Exceptions in IIAs: Increasing Legitimacy or Uncertainty?' in Armand De Mestral and Céline Lévesque (eds), Improving International Investment Agreements (Taylor and Francis, 2013) 267.

88 Kurtz (n 80) 10. 
commercial presence and in the regulation of new sectors such as e-commerce and cross-border data flows.

Third, the two regimes have overlapping subject-matter jurisdiction, with a number of measures having been adjudicated either simultaneously or successively in WTO dispute settlement and before an ad hoc arbitral tribunal appointed under an IIA. ${ }^{89}$

Fourth, as noted above, the two regimes face many common problems or issues, meaning that they often perform comparable functions. For example, both regimes allow for derogation from their primary norms where justified by another public interest, such as protection of public health or the environment, using different forms of balancing or proportionality analysis. ${ }^{90}$

These four factors, both individually and collectively, suggest that despite having been treated as separate regimes historically, international trade and international investment law are suitable subjects for comparative study. In carrying out this comparative analysis, however, the different institutional structures, purposes and histories of each regime must be borne in mind. The use of functional comparative law has at times been criticised for examining legal rules or processes in the abstract, without sufficient consideration of the context and structure in which those rules operate. ${ }^{91}$ In this volume, like other scholars undertaking comparative work in the field of international economic law, we remain mindful of the unique features of each regime and consider how these differences shape the incorporation or application of principles in each regime.

\section{OUTLINE OF THE FOLLOWING CHAPTERS}

Part I of the book includes four chapters, each of which surveys and analyses the use of a principle or concept that is central to both the fields of international

89 See, eg, (i) challenges to Australia's tobacco plain packaging laws: Philip Morris $v$ Australia, Decision on Jurisdiction; Appellate Body Reports, Australia - Tobacco Plain Packaging; (ii) the softwood lumber disputes involving the United States and Canada: see, eg, Canfor $v$ United States, Decision on Preliminary Question; Panel Report, US - Offset Act (Byrd Amendment); (iii) the sweeteners dispute between Mexico and the United States: Archer Daniels v Mexico, Award; Corn Products $v$ Mexico, Decision on Responsibility; Panel Report, Mexico - Corn Syrup; Appellate Body Report, Mexico - Taxes on Soft Drinks.

${ }_{90}$ For general comparative discussion of how the two regimes engage in balancing competing interests, see, eg, Markus Wagner, 'Regulatory Space in International Trade Law and International Investment Law’ (2014) 36(1) University of Pennsylvania Journal of International Law 1; Cho and Kurtz (n 81); Henckels (n 11).

91 Geoffrey Samuel, An Introduction to Comparative Law Theory and Method (Hart Publishing, 2014) 80-81. 
trade law and international investment law: procedural fairness, reasonableness, necessity testing and non-discrimination. For each of these four topics we identify the relevant treaty rules and how those provisions have been interpreted and applied by tribunals. From this detailed analysis, we seek to identify the extent to which there is a cohesive principle across international economic law. In this respect, in each chapter we are looking not just for a common topic or theme which can be labelled a 'principle'. Instead, we try to identify a principle with greater content and specificity. For example, in Chapter 5 the principle we identify is not the broad theme of 'non-discrimination'. Rather, the 'principle' identified in that chapter after analysing the relevant legal rules is that like products, services and investors should be accorded equal treatment with the aim of eliminating protectionist government action, but that differential treatment may be permissible to achieve legitimate regulatory purposes.

The selection/inclusion of principles has been made, in large part, on the basis of Dworkin's concept of weight, ${ }^{92}$ with a focus on principles that are prominent in both WTO law and international investment law. Some principles have 'weight' as a result of their reinforcement through several core treaty provisions (eg, non-discrimination rules), while others derive their 'weight' from their importance across a number of legal regimes and contexts (eg, procedural fairness). Even using these criteria there are many other principles that would have been worthy of closer consideration in this volume, such as good faith or proportionality. However, in Part I of this volume we have opted for a detailed consideration of select principles, rather than attempting a more comprehensive but high-level discussion of all potentially relevant principles. Those principles that are not examined in this volume have received comparative treatment elsewhere and will make important subjects for future work. ${ }^{93}$

We also note that the boundaries between principles may not always be clear. While proportionality is often viewed as a principle of law, ${ }^{94}$ it is also a method of assessing the legitimacy of measures that interfere with a protected interest. As a method of assessment, proportionality includes several stages of analysis, which usually include necessity testing to determine whether that measure was the least-restrictive means of achieving its objective. ${ }^{95}$ In this way, proportion-

\footnotetext{
92 Dworkin (n 20) 36-40.

93 On good faith, see Mitchell, Sornarajah and Voon (n 11). On proportionality, see Henckels (n 11); Thomas Cottier et al, 'The Principle of Proportionality in International Law: Foundations and Variations' (2017) 18(4) The Journal of World Investment \& Trade 628.

94 See, eg, Mitchell (n 10) ch 6.

95 For a more detailed discussion of the stages of proportionality analysis, see Alec Stone Sweet and Jud Mathews, 'Proportionality Balancing and Global
} 
ality and necessity testing are overlapping concepts. ${ }^{96}$ Moreover, a specific treaty provision may be influenced by more than one principle. In Chapter 3 , we consider GATT Article X:3(a), which requires reasonable, impartial and uniform administration of measures. While we consider that provision in the context of the principle of reasonableness, we note that GATT Article X:3 more generally also reflects the principle of procedural fairness. ${ }^{97}$

Part II of the book then considers how these principles apply in two increasingly important sectors of government regulation: the management of cross-border data transfers and the use of prudential measures to protect the integrity and stability of financial systems. Examining the application of principles in these specific sectors demonstrates their adaptability to new technologies and new areas of government regulation, but also highlights the importance of general and abstract principles being refined into rules that are appropriately tailored to address contemporary challenges.

Constitutionalism' (2008) 47 Columbia Journal of Transnational Law 72, 75-76; Henckels (n 11) ch 2.

96 As we explain in Chapter 3, the principle of reasonableness as a form of rationality testing is also comparable to the suitability testing that is often undertaken at the first stage of proportionality analysis.

${ }_{97}$ See Appellate Body Report, Thailand-Cigarettes (Philippines), [202]. We consider GATT art X:3(b) in the context of procedural fairness. 